\title{
A JUDICIALIZAÇÃO DA POLÍTICA, O ATIVISMO JUDICIAL: DESAFIOS DA
} DEMOCRACIA NO BRASIL

\author{
THE JUDICIALIZATION OF POLITICS, JUDICIAL ACTIVISM: CHALLENGES \\ OF DEMOCRACY IN BRAZIL
}

\author{
Adriane de Oliveira Ningeliski ${ }^{1}$ \\ Laura Jane Ribeiro Both ${ }^{2}$
}

\section{RESUMO}

As mudanças da ordem econômica, valorativas e de pensamento da sociedade, tem levado cada vez mais o Poder Judiciário a intervir ativamente em questões que precipuamente estariam fora de sua competência, por evidente inércia dos demais poderes, os quais, politicamente eleitos e representantes da maioria, acabam não cumprindo seu papel de proteção e garantia da coletividade. Essa interferência tem levado a tensões entre os poderes, fazendo surgir uma discussão acalorada da possível ofensa ao princípio democrático. Assim, a partir do método dialético, a presente pesquisa busca evidenciar essas inquietudes.

Palavras-chave: Judicialização da política; ativismo judicial; democracia; separação de poderes; poder Judiciário.

\begin{abstract}
The changes of the economic order, of values and thoughts of society, have increasingly led the Judiciary to intervene actively in issues that, primarily, would be out of its competence, due to an evident inertia of the other State powers, which are politically elected and as representatives of the majority, end up not fulfilling their role of protection and guarantee of the collectivity. This interference has led to tensions between the powers, giving rise to a heated discussion about a possible offense to the democratic principle. Thus, from the dialectical method, the present research seeks to highlight these concerns.
\end{abstract}

Keywords: Judicialization of politics; judicial activism; democracy; separation of powers; Judiciary.

\footnotetext{
${ }^{1}$ Mestre em Direito pelo Centro Universitário Autônomo do Brasil - UNIBRASIL, Curitiba, Paraná. Professora do Curso de Direito da Universidade do Contestado-UnC-Campi Canoinhas/SC e Mafra/SC. Email: adrianeoliveira@netuno.com.br

${ }^{2}$ Doutora em Educação Professora/Pesquisadora do Programa de Mestrado em Direito do Centro Universitário UniBrasil em Curitiba/PR.
} 


\section{INTRODUÇÃO}

O conflito é inerente ao ser humano, e essa conflituosidade tem feito com que aumentasse o número de conflitos não resolvidos no seio da sociedade e desaguando no judiciário, à procura de um árbitro.

Entretanto, além dessa conflituosidade inerente, outras questões têm ido parar no Judiciário, as quais precipuamente são atípicas às suas funcionalidades, como a efetivação de políticas públicas que teoricamente são de responsabilidade dos poderes políticos, os quais acabam passando maneira inexpressiva pelos problemas, não os resolvendo.

Esses direitos têm guarida na Constituição, e quando não promovidos por quem é devido, obrigam ao Poder Judiciário a suprir essa falta, acabando por vezes a estender seu poder de atuação, sobre o âmbito de atuação dos demais poderes. Estes, por inércia, são obrigados pelo Judiciário, a cumprir suas obrigações típicas.

Tal atitude proativa do Judiciário gera, por vezes, tensões entre os poderes que se veem obrigados a cumprir as determinações judiciais, sem escolha.

Essa atuação estendida nada mais é do que o chamado ativismo judicial, que se instala quando da necessidade de preenchimento de lacunas deixadas pelos poderes políticos, ao inaplicarem ou desrespeitarem garantias constitucionais previstas, de proteção de direitos fundamentais.

Assim, a presente pesquisa de forma dialética procura verificar se essas atuações proativas do Poder Judiciário e/ou a intensa judicialização de demandas, não estariam claramente desrespeitando o princípio democrático.

Dessa forma, o presente trabalho divide-se em 3 capítulos a saber: primeiro trata sobre a judicialização da política, sua conceituação e aplicação; o segundo, sobre o ativismo judicial propriamente dito, conceituando-se, promovendo justificativas e críticas a sua aplicação; e por derradeiro, faz-se uma incursão de maneira sucinta no âmbito da democracia, demostrando aspectos de garantia, justificando a importância da existência do ativismo judicial.

\section{JUDICIALIZAÇÃO DA POLÍTICA}

O Constitucionalismo Social surgiu com o colapso da sociedade liberal, desgastada com promessas não cumpridas (igualdade, liberdade, cidadania, etc), o aparecimento do 
capitalismo (surgido a partir das revoluções industriais burguesas) e o aumento das demandas sociais e políticas, após a Primeira grande Guerra Mundial (FERNANDES, 2008).

A partir desse novo paradigma, é cediço salientar que a sociedade de massas do pósPrimeira Guerra, deixou de ser formada somente por indivíduos proprietários privados, em uma agora existente sociedade conflituosa, partida em vários grupos, coletividades, classes de partidos e facções em disputa, cada qual buscando seus próprios interesses (FERNANDES, 2008).

O Código de Napoleão teve grande influência nas codificações posteriores a ele, doutrina individualista e voluntarista, que acabou influenciando diretamente o Código Civil Brasileiro de 1916, o qual tinha em si diplomas civis como verdadeiras constituições de direito privado, com segurança aos negócios e suas regras, sem intervenção estatal, principalmente na área econômica (SANTANA, 2012).

No entanto, com o passar do tempo essa estabilidade cai em declínio na Europa, metade do século XIX, 1920 aqui no Brasil. Vários fatores sociais, como a Primeira grande Guerra mundial, levaram a mudanças que balizaram a necessidade de uma maior intervenção estatal na economia (SANTANA, 2012).

Não existe mais aquele Estado liberal neutro, longe dos conflitos sociais, mas um Estado que se assume como agente conformador da realidade social e que busca, inclusive, estabelecer formas de vida plenas, concretas, impondo nas pautas públicas um estilo de vida adequado (FERNANDES, 2008).

O Estado-assistencial levou à expansão dos direitos sociais, bem como arrebanhou a classe trabalhadora para dentro da sociedade de consumo. Com isso houve crescimento sem número dos conflitos sociais (SILVA, 2005).

Assim, o Estado liberal do século XIX, não interventivo, teria sido substituído pelo Estado social, com muitas obrigações a cumprir, gerando um indicativo de crise (FONSECA, 2011), ou seja, sai do modelo de Estado que não interfere nas relações para um Estado que passa a agir efetivamente nas relações privadas.

Os novos direitos sociais levaram a novos conflitos, que consequentemente passaram a ser conflitos jurídicos cuja dirimição caberia em princípio aos tribunais, litígios sobre vários tipos de relações sociais, como a relação de trabalho, segurança social, habitação, consumo. Além disso, a integração da mulher no Mercado de trabalho aumenta a interação dessa classe trabalhadora (SANTOS, 1994). 
Nesse contexto, além dos interesses conflitantes entre os cidadãos chegarem ao judiciário, outras questões passam pelo seu crivo, como questões políticas, que no seu cerne saem do poderio legislativo, que deveria prevê-las e passam ao poder judiciário (ESTEVES, 2006).

Esse fenômeno tem sido chamado no mundo acadêmico, de "judicialização dos conflitos sociais" ou, tomando uma amplitude que revele a problematização da atividade política, “judicialização da política”, a qual, muitas das vezes, traz embutidas questões de ordem social (ESTEVES, 2006).

Pelo processo de judicialização, o Judiciário passa a exercer funções atípicas a sua atribuição, que em primeira instância deveriam ser exercidas pelo legislativo ou pelo executivo, porém acabam caindo no Judiciário, propiciando a expansão e consolidação da cultura do "não deu certo, vá para a justiça" (FONTAINHA, 2009).

Isso se deve ao fato de que o Judiciário tem uma função de destaque no que tange a garantia de que o Estado Democrático de Direito, consolide-se e efetive-se.

\begin{abstract}
O Poder Judiciário, um dos três poderes clássicos do Estado, vem assumindo (e a cada dia de forma mais acentuada) uma função fundamental na efetivação do Estado Democrático de Direito. É o guardião da Constituição, cuja finalidade, basicamente, repousa na preservação dos valores e princípios que a fundamentam - cidadania, dignidade da pessoa humana, valores sociais do trabalho e da livre iniciativa, além do pluralismo político (Art. 1o, CF/88) (SENA, 2007, p.01).
\end{abstract}

Apesar de suas funções de destaque e de sua importância no contexto de aplicação da Justiça, essa confiança desenfreada fez com que se consolidasse a cultura do litígio na sociedade brasileira, até então muito confortável com a ideia do conflito e de que tudo fosse levado ao Judiciário e, ainda, que só existiria justiça com a decisão do juiz togado (NETO, 2013).

\footnotetext{
A nossa realidade é caracterizada por uma cultura demandista, uma vez que as pessoas se acostumam a confiar a decisão de suas contendas a um terceiro imparcial, como se fosse mais capaz do que os próprios conflitantes de promover a justiça no caso concreto. Além disso, o magistrado, em regra, adota uma postura direcionada para solução impositiva do conflito, através da sentença, e não para sua pacificação por meio da promoção do diálogo (SILVA, 2013, p. 161).
}

O brasileiro se caracteriza pelo seu espírito demandista (WARAT, 1999), o que por via de consequência faz com que a procura do judiciário seja uma constante ação, que dá azo à crise de efetividade que assola esse poder. 
VIANNA e BURGOS quando retratam a judicialização da política relembram que a invasão do direito sobre o social anda na regulação dos setores mais vulneráveis, em um processo de substituição do Estado e dos recursos institucionais pelo judiciário (VIANNA e BURGOS, 2007).

O juiz torna-se protagonista direto da questão social, em que sem política, sem partidos ou uma vida social organizada, o cidadão volta-se para ele, mobilizando o arsenal de recursos criado pelo legislador, a fim de lhe proporcionar vias alternativas para a defesa e eventuais conquistas de direitos(VIANNA e BURGOS, 2007).

Nas últimas décadas o Brasil e outros países ocidentais, que também adotaram o constitucionalismo, vêm experimentando a transferência de parte do poder político para os tribunais. Em certa medida, pode-se dizer que este poder tem saído da esfera de representação parlamentar para o âmbito do Poder Judiciário (BARBOZA, 2014).

Pois, “esse fenômeno é definido como judicialização da política e pode significar tanto a transferência das decisões do campo parlamentar ou executivo para as Cortes como o aumento dos métodos judiciais de tomada de decisões para além dos tribunais" (BARBOZA, 2014, P. 93).

\footnotetext{
Os direitos fundamentais têm íntima ligação com respeito, garantia e defesa do princípio da dignidade da pessoa humana. O ser humano é fim em si mesmo, não podendo ser coisificado para servir de meio ao atingimento de qualquer fim. Têm direitos que decorrem desta condição e desta dignidade, que não é atribuída, posto que inerente, mas reconhecida. (OLIVEIRA, 2006, p. 121).
}

Em tempo, é importante ressaltar que uma imensa quantidade de ideais e direitos esculpidos na Constituição Federal de 1988, representaram um alicerce rochoso e firme para o enganjamento dos grupos sociais na efetivação dos direitos, bem como, simbolizaram o caminho trilhado para que muitas questões políticas fossem levadas a apreciação do judiciário (POLI, 2013).

\section{ATIVISMO JUDICIAL}

A origem do ativismo Judicial está no Movimento do Direito Livre, nascido no fim do século XIX e início do século XX, como forma de reação ao formalismo jurídico da jurisprudência de interesses (SANTOS, 2013).

O Poder Judiciário, ao apreciar demandas individuais e condenar o Estado ao pagamento de medicamentos, concede maior e máxima eficácia a algumas normas 
constitucionais de sentido abstrato, como prevê o terceiro fundamento da República, a dignidade da pessoa humana, preservando esses princípios em um papel de retirada da missão constitucional, os juízes condenam o Estado ao pagamento de prestações aos indivíduos necessitados, numa ânsia de satisfação ao caso individual apresentado (ÁVILA, 2013).

Após a promulgação da Constituição Federal de 1988, garantindo direitos de forma democrática, bem como com a recente, apesar de insipiente, concientização da população acerca dos direitos estabelecidos na Carta Magna, passou a fazer parte da pauta de discussões do povo brasileiro os motivos da inefetividade das garantias constitucionais e também as formas possíveis de resolução de tal problema, surgindo, como uma das alternativas a otimização do ativismo judicial (JUNIOR, 2011, p. 171).

Assim, o ativismo judicial representa um movimento intenso do juiz (intérprete) na decodificação da Constituição e na potencialização do sentido das normas, uma forma de contorno ao processo político majoritário quando este fica inerte as necessidades da sociedade (BARROSO, 2012).

Na prática, o campo de atuação do ativismo pode estar localizado nas diversas áreas do direito, gerando polêmica quando chega ao âmbito do direito constitucional, em razão da sua característica de ordenação dos poderes estatais, suas limitações, e garantidor dos direitos fundamentais (SANTOS, 2013).

O ativismo pode ser entendido de duas formas, uma em razão do controle de constitucionalidade e outra em razão dos precedentes judiciais.

Em um primeiro momento poderia se chegar à conclusão de que a ideia de ativismo judicial poderia estar ligada ao aumento de atos invalidados pelo judiciário em razão controle de constitucionalidade das normas, sendo nesse viés, considerada ativista, e não a declaração de inconstitucionalidade em si, mas o simples fato de que a inscontitucionalidade seja, não confirmada, mas possível (BERMAN, 2015).

Já, um segundo entendimento sobre ativismo, é o que o conecta ao fato de não se observar os precedentes judiciais existentes ao decidir uma determinada questão (BERMAN, 2015).

\footnotetext{
A idéia de ativismo judicial está associada a uma participação mais ampla e intensa do Judiciário na concretização dos valores e fins constitucionais, com maior interferência no espaço de atuação dos outros dois Poderes. A postura ativista se manifesta por meio de diferentes condutas, que incluem: a) a aplicação direta da Constituição a situações não expressamente contempladas em seu texto e independentemente de manifestação do legislador ordinário; b) a declaração de inconstitucionalidade de atos normativos emanados do legislador, com base em critérios menos rígidos que os de patente e ostensiva violação da Constituição; c) a imposição de condutas ou de abstenções ao Poder Público, notadamente em matéria de políticas públicas. As origens do ativismo judicial remontam à jurisprudência
} 
norte-americana. Registre-se que o ativismo foi, em um primeiro momento, de natureza conservadora (BARROSO, 2012, p. 25-26).

Assim, o que se percebe é que após o fim da Segunda Grande Guerra Mundial surgem documentos normativos preocupados com a preservação e garantia dos direitos humanos de forma universal, tanto no âmbito nacional, quanto supranacional; internamente, as Constituições têm a função de enunciar os direitos que serão protegidos, acompanhando os mecanismos de acesso às instâncias que garantam a aplicabilidade das determinações da Constituição, através do controle de constitucionalidade (BERMAN, 2015).

\footnotetext{
A expansão da autoridade do Supremo Tribunal Federal e dos tribunais em geral não é, no entanto, um fenômeno estritamente brasileiro. Há, hoje, uma vasta literatura que busca compreender este fenômeno de avanço do direito em detrimento da política e conseqüente ampliação da esfera de autoridade dos tribunais em detrimento dos parlamentos (VIEIRA, 2008, p. 442).
}

O judiciário passou de uma função de contenção de excessos para a determinação de medidas necessárias, ante a não atividade da Administração pública, judicializando os direitos sociais, como derradeira alternativa para sua efetivação, tomando medidas de coação indireta, para responsabilizar gestores públicos (SANTOS, 2013).

Para alguns analistas, o fortalecimento da autoridade dos tribunais tem sido uma
consequência imediata da expansão do sistema de mercado, em plano global. Aos
olhos dos investidores, os tribunais constituiriam um meio mais confiável para
garantir a segurança jurídica, estabilidade e previsibilidade do que legisladores
democráticos, premidos por demandas "populistas" e necessariamente pouco
eficientes, de uma perspectiva econômica (VIEIRA, 2008, p. 442).

Um exemplo recorrente na sociedade brasileira, de ativismo judicial, é a imposição de condutas ou proibições, como o que ocorre com a concessão de medicamentos e determinação de terapias mediante decisão judicial, fato ainda analisado superficialmente pelo Supremo Tribunal Federal, mas abarrotam as justiças estadual e federal em todo o país, condenando a União, ou Estado ou o Município, ou muitas vezes os três ao mesmo tempo, para custear medicamentos e terapias aos cidadãos (BARROSO, 2012).

Como se sabe, os problemas relacionados aos direitos sociais não são dessa ordem. $\mathrm{O}$ que ocorre, nesse âmbito, é a falta de realização dos direitos, decorrente em geral de uma omissão estatal ou de uma ação insuficiente. Em suma: tanto o conceito do que é protegido quanto o conceito de intervenção têm que ser modificados" (SILVA, 2009, p. 77).

É de se concluir que judicialização da política e o ativismo judicial são parentes próximos, podendo até dizer que são primos, com mesma família, mas não tem a mesma 
origem, pois não são gerados pelas mesmas causas imediatas. A judicialização, no Brasil, é uma circunstância que vem do modelo constitucional adotado e não do exercício deliberado de vontade política, pois o Judiciário decide porque é o que lhe cabe fazer, não há alternativas, cabe ao juiz conhecer da matéria, e decidí-la (BARROSO, 2012).

Enquanto o ativismo judicial é uma atitude, há a escolha de um modo específico e ativo (proativo) de interpretar a Constituição, com extensão de seu sentido e alcance, instalando-se comumente em situações de retração do Poder Legislativo, um desligamento entre a classe política e a sociedade civil, obstando que as demandas sociais sejam atendidas de maneira efetiva (BARROSO, 2012).

Vários são os aspectos a serem analisados no que tange ao ativismo judicial e a judicialização da política, mas as críticas devem ser estudadas mais detidamente, por trazerem à tona discussões, sobre legitimidade e a capacidade do Poder Judiciário atuar fora de sua seara, princípio da separação dos poderes, democracia, etc.

\subsection{Pontos Controvertidos}

Nesse momento da pesquisa, busca-se apresentar em quais pontos aparecem divergências na doutrina quanto à afronta ao princípio democrático.

\subsubsection{Separação dos Poderes}

A discussão sobre a grande interferência do Poder Judiciário nos demais poderes, pode ter como fundamento uma doutrina muito antiga, Montesquieu, que previa a importância, de que os poderes deviam estar separados e autônomos, a fim de que fossse promovida a liberdade e evitada a tirania.

\footnotetext{
Quando na mesma pessoa, ou no mesmo corpo de magistratura, o poder legislativo está reunido juntamente com o poder executor, não há liberdade; porque se pode recear que o mesmo monarca ou o mesmo senado façam leis tirânicas para as executar tiranicamente.Tampouco existe liberdade se o poder de julgar não for separado do poder legislativo e do executivo. Se estivesse unido ao poder legislativo, o poder sobre a vida e a liberdade dos cidadãos seria arbitrário, pois o juiz seria legislador. Se estivesse unido ao poder executivo, o juiz poderia ter a força de um opressor (MONTESQUIEU, 2000, p. 168).
}

Nesse contexto, de forma breve segue uma definição da atuação e limites dos poderes Legislativo, Executivo e Judiciário. 


\subsubsection{Poder Legislativo}

O Poder Legislativo tem como função típica a criação das leis, as quais possam instrumentalizar os programas políticos dos governos democráticos, bem como leis que promovam a realização dos fins da Constituição, obstando abusos. Para tanto, conferiu o poder de veto ao Executivo, e deu ao Judiciário o poder de controle e invalidação das normas que não se compatibilizarem com a Constituição, havendo para garantia o sistema dos freios e contrapesos, permitindo a Constituição controles mútuos e não sujeições, dentro dos limites (ÁVILA, 2013).

\subsubsection{Poder Executivo}

A função típica do Poder Executivo é a execução dos comandos da norma, ou seja, concretizar o que a lei manda, começando essa execução pela Constituição, competindo ainda a criação de infra-estrutura, para a promoção dos direitos fundamentais elencados na carta magna (ÁVILA, 2013).

\subsubsection{Poder Judiciário}

O Poder Judiciário tem como função precípua assegurar a aplicação da lei, mediante provocação do sujeito prejudicado pelo descumprimento dos deveres decorrentes do ordenamento jurídico, uma vez que toda norma exprime um dever-ser (KELSEN, 2012).

Assim, pelo que determina a Constituição, o Judiciário deve fazer valer o que deve ser, seja como descrito pela norma, estando nesse aspecto o caráter constitutivo das decisões judiciais (KELSEN, 2012).

\footnotetext{
Um dos motivos da existência do Poder Judiciário é a sua função de aplicar o direito com independência, impondo a sua observância indistinta e na busca da pacificação social. As garantias que the foram atribuídas, na realidade foram outorgadas como prerrogativas para o imparcial, independente e seguro cumprimento de seu mister constitucional (SENA, 2007, p. 01).
}

Apesar de cada poder ter suas funções típicas, já elecandas acima, vive-se uma crise de legitimidade representativa e funcionalidade do Poder Legislativo e do Executivo, corroborando para a interferência do Poder Judiciário, justificado pela Constituição, prolatando 
decisões para suprimir as omissões e inovar a ordem (BARROSO, 2012).

Portanto, o Poder Judiciário acaba atendendo as demandas da sociedade, as quais o Poder Legislativo não foi capaz de fazer (BARROSO, 2012).

Assim, exercício ativo do Judiciário, leva a inovações na ordem jurídica e social, com decisões de natureza e efeitos políticos, na ânsia de chegar ao status de verdadeiro poder, que cumpre suas tarefas (DOBROWOLSKI, 1995).

\title{
3.1.2 Críticas ao Ativismo Judicial
}

A crítica consiste em como ficariam os standards constitucionais, emanados do Princípio do Estado de Direito e seus pressupostos, como democracia, separação dos poderes, legalidade e segurança jurídica, pois as decisões alocativas de recursos não são satisfativas à exigência de proporção dos meios em detrimento aos fins, causando mais desvantagens do que vantagens na promoção da Constituição unitariamente considerada. $\mathrm{O}$ fato justificador do ativismo, fazer justiça ao caso concreto, perde o sentido quando pode violar elementos parciais contidos no próprio conceito de justiça, como são a segurança jurídica e a igualdade (ÁVILA, 2013).

\begin{abstract}
A realização da Constituição passa pela atividade intelectual de interpretar/aplicar conceitos e categorias jurídicas de elevado grau de generalidade e abstração, mesmo que para tanto seja necessário abraçar competências institucionais que ordinariamente tocam a outros Poderes. O problema com essa sorte de postura seria estarmos substituindo a vontade do soberano que criou a lei e a Constituição pela vontade do intérprete (TEIXEIRA, 2012, p. 48-49).
\end{abstract}

Essa crise de legitimidade, enfrentada pelo Poder Legislativo no Brasil e no mundo, demonstra uma necessidade de reforma política. Num mundo ideal as decisões ativistas são eventuais, em tempos determinados, e não recorrentes como acontece hoje, pois para que uma democracia seja sólida, a atividade política deve extensa, o Congresso deve ser ativo e eivado de credibilidade (BARROSO,2012).

Outra crítica seria que, para além de uma simples reação normal, inerente a sua função, estaria o judiciário excedendo os seus parâmetros institucionais, num verdadeiro desvio de conduta (FERREIRA, 2014).

Em meio a toda essa história de crise, três pontos devem ser levantados e analisados de forma mais aprofundada, quais sejam: os riscos para a legitimidade democrática, politização indevida da justiça e limites da capacidade institucional do Judiciário (BARROSO, 2012).

No que tange ao primeiro ponto, a legitimidade democrática, estaria o fato de que o 
poder de decisão estaria nas mãos dos membros do Judiciário, que não chegam aos cargos, pelo voto, porém estariam atuando politicamente ao invalidar os atos dos outros dois Poderes, que tiveram respaldo da vontade popular (BARROSO, 2012).

Portanto, a jurisdição constitucional bem exercida é antes uma garantia para a democracia do que um risco. Impõe-se, todavia, uma observação final. A importância da Constituição - e do Judiciário como seu intérprete maior - não pode suprimir, por evidente, a política, o governo da maioria, nem o papel do Legislativo (BARROSO, 2012).

O ponto crucial da crítica é o fato de os juízes não serem eleitos. Dessa forma, não poderem intervir diretamente nos gastos públicos e nas escolhas de políticas econômicas por falta óbvia de legitimidade, a qual seria do legislativo e executivo, posição alcançada através da vontade popular. Quando o juiz age de forma ativista, segundo essa crítica, estaria indo contra o poder do povo (JUNIOR, 2011).

Sem embargo, a objeção democrática ao processo de constitucionalização também se manifesta neste cenário, pois é preciso avaliar até que ponto é legítimo, numa democracia, amputar a liberdade de conformação do legislador em nome da irradiação das normas constitucionais, sobretudo diante da constatação de que o grande "agente" desta irradiação é o juiz, que não é eleito e não responde politicamente perante o povo (SARMENTO, 2006, p. 25).

Ferreira questiona a legitimidade dos excessos cometidos pela atuação do poder judiciário, no que tange aos novos paradigmas, mesmo que esse ativismo estivesse conduzindo uma aproximação entre o Supremo Tribunal Federal e a população (FERREIRA, 2014).

\footnotetext{
Os riscos de uma atividade judicial ativista, tomada sua definição como a atuação do poder judiciário para além dos limites do sistema normativo, com base em uma atividade de interpretação, construção e aplicação do Direito fundada em parâmetros normativos de uma textualidade vaga, de baixa densidade semântica e conceitual, cuja hermenêutica propõe o rompimento dos limites entre a Moral e o Direito, residem fundamentalmente no enfraquecimento do caráter deontológico do Direito, heterolimitador da norma, utilizando aqui a crítica de Jürgen Habermas, na medida em que o campo argumentativo e de fundamentação das decisões abre-se para fronteiras de difícil aferição (FERREIRA, 2014, p. 140-141).
}

Sob uma análise superficial, mas contextualizada, pode se pensar que o Judiciário, ao não passar pelo processo democrático não tenha legitimidade para atuar de forma ativista, como já levantado por outros doutrinadores no presente texto. Entretanto, esquece-se que a Corte Constitucional, o Supremo Tribunal Federal, possui ministros escolhidos pelo Presidente da República e confirmados pelo Senado, estes eleitos pelo povo democraticamente. Ou seja, por via indireta, os ministros do STF também são escolhidos pela população, onde depreende-se que invalidar leis poderia ser um ato tão político quanto criá-las (ÁVILA, 2013), isto é, o Poder 
Judiciário, tem legitimidade sim para atuar de forma ativista.

Já em um segundo ponto está o risco de politização da Justiça. Pode-se dizer que no mundo de hoje, não cabe mais dizer que direito é política, em “uma visão distorcida do mundo e das instituições faria uma equiparação dessa natureza, submetendo a noção do que é correto e justo à vontade de quem detém o poder" (BARROSO, 2012, p. 29).

A dificuldade conceitual e funcional está em diferenciar direito e politica, pois o ativismo judicial é um sintoma das sociedades de massa pós-modernas, não satisfeitas com as prestações de serviços públicos cujos direitos fundamentais não estão tutelados nos moldes do Estado moderno, onde mais do que discutir separação de poderes, é saber quais os limites entre Direito e Política (TEIXEIRA, 2012).

\begin{abstract}
A chamada "politização do judiciário", ou seja, o exercício de uma postura ativa por parte do Judiciário, fez com que temas que sequer mereciam atenção do Poder Legislativo, por exemplo, passassem a fazer parte da pauta das discussões dos membros do executivo e legislativo, inclusive com relação às leis orçamentárias, que na maioria das vezes eram aprovadas sem levar em consideração um planejamento efetivo e, da mesma forma, executadas de acordo com as "vontades políticas" dos membros do executivo e, também, legislativo (JUNIOR, 2011, p.172 ).
\end{abstract}

A terceira crítica refere-se à capacidade institucional do Judiciário e seus limites, a pedra de toque, para exploração seriam dois pontos decorrentes: as capacidades institucionais e os efeitos sistêmicos (BARROSO, 2012).

As capacidades institucionais, tratariam do poder que estaria mais apto a decidir em determinada matéria, pois temas envolvendo aspectos de grande complexidade, nem sempre teriam árbitros qualificados (BARROSO, 2012).

No entanto, é importante ressaltar que o juiz ativista não toma a decisão sozinho. Apesar da crítica, ele se serve do auxílio de outros profissionais especialistas, com os conhecimentos técnicos necessários para se proferir a decisão adequada, os peritos, fato que se levado às últimas consequências também acometeria o legislativo e o executivo (JUNIOR, 2011), assim a crítica não subsistiria.

Quanto ao risco de efeitos sistêmicos imprevisíveis e indesejados, podem levar a situação que recomenda cuidado por parte do Judiciário, dado que o juiz conhece o caso em particular, mas não o contexto, e nem os efeitos que suas decisões podem causar na economia ou na prestação de serviço público (BARROSO, 2012).

\title{
3.1.3 Justificativas para o Ativismo Judicial
}


Quando num mundo em que a fragilidade do homem fica evidenciada pela sociedade esmagadora e globalizada, alguém deve intervir em seu nome, combatendo frente a frente com a extrema força dos demais poderes. Assim, nesse contexto emerge o Poder Judiciário, como verdadeiro representante da Justiça na terra.

\footnotetext{
Atualmente, quando os meios da técnica e a atividade econômica e social possuem aptidão para causar graves efeitos lesivos às populações massificadas, e perante um crescimento desorbitado da atuação estatal, capaz de violar direitos de incontável número de pessoas, é preciso um Judiciário que não se abstenha perante esses poderes agigantados, mas que tenha condições para enfrentá-los em patamar de igualdade (DOBROWOLSKI, 1995, p. 99).
}

O ministro Celso de Mello, reforçando a importância da atuação do Poder Judiciário, ressalta que o ativismo é uma necessidade institucional do STF em momentos excepcionais, pois quando o poder público se omite ou retarda sua atuação no cumprimento de suas obrigações, principalmente no que for ofensivo à constituição, o Judiciário não pode ficar inerte (MELLO, 2008).

\section{ATIVISMO JUDICIAL E DEMOCRACIA}

A Carta Magna prevê que o Brasil é um Estado Democrático de Direito, onde todo o poder emana do povo, e o importante corolário do princípio democrático, seria o pluralismo político, que coloca o Poder Legislativo em destaque, e o Congresso Nacional, a manifestação do seu vigor (ÁVILA, 2013).

O Estado de Direito, assim, serve à pessoa e à sociedade. Todos - e cada um - abdicam parte de sua individualidade em prol de uma mediação técnico-jurídica, instrumentada e concretada em realidades distintas, que modernamente vem ganhando o nomem iuris de Estado de Direito (REVERBEL, 2009, p. 02).

A democracia pode ser conceituada, a partir de cinco critérios: a participação efetiva, a igualdade de voto; o entendimento esclarecido; o controle do programa de planejamento; inclusão de adultos (DAHL, 2009).

Para justificar a democracia, Dahl relata que a mesma teria consequências desejáveis, como evitar a tirania, conceder direitos essenciais, dar liberdade a todos, promover a autodeterminação, conceder autonomia moral e desenvolvimento humano, proteger interesses pessoais essenciais, garantir igualdade política, e nas democracias modernas, busca a paz e a prosperidade (DAHL, 2009). 
Assim, uma vez que a democracia tem um papel preponderante nas sociedades modernas, é cediço estabelecer critérios de como ela pode ser preservada, apesar da existência do ativismo judicial, que de certa forma ameaça a força da democracia.

A função judicial pode não ser a mais democrática, distanciando propositalmente de seu núcleo, para poder controlar o próprio Direito, ao trazer para si a autoridade sobre a interpretação dos conceitos abertos, com extensa carga valorativa. Assim, o ativismo judicial tende a deslocar para o campo do processo judicial a atividade típica que se desenvolve em um processo político democrático (FERREIRA, 2014).

O fato é que a Democracia, apesar de seus diversos significados, que tendem a alterar seus parâmetros de interpretação, ainda num contexto de descrédito, é certamente primordial à manutenção das vigas mestras que mantém em pé o próprio Estado de Direito (FERREIRA, 2014).

Ferreira propõe como forma de equilibrar os princípios democráticos e o ativismo judicial, o desenvolvimento de uma postura de autocontenção pelos membros das Cortes Superiores, de forma a evitar excessos na intervenção judicial; a adoção de um positivismo renovado; o incremento da qualidade argumentativa dos Tribunais (FERREIRA, 2014).

Sarmento entende que há como equilibrar os pontos de tensão, utilizando os seguintes métodos, quais sejam: emprego de uma metodologia racional, intersubjetivamente controlável e transparente; a democratização do próprio exercício da jurisdição constitucional, a adoção, pelos juízes, de uma postura de moderação e de respeito diante das decisões adotadas pelos demais poderes (SARMENTO, 2006).

A discussão está na legitimidade do Poder Judiciário intervir em políticas públicas, as quais necessariamente seriam de incumbência dos poderes diretamente eleitos pelo povo, quais sejam Poder Legislativo e Executivo. Contudo, há um favoritismo para com as decisões judiciais que alocam recursos públicos, tendo o Poder Judiciário como missão suprir o déficit educacional da população brasileira para o exercício consciente de poder de voto e dos direitos de liberdade. Isso porque, nesse contexto, direitos mais básicos do indivíduo seriam pressupostos da discussão que envolve a democracia, uma vez que quando o Judiciário atua, nesse campo, mesmo através de ações individuais, estaria em consonância com a democracia (ÁVILA, 2013).

\subsection{Guardião da Constituição}


Quando se usa o termo guardião da Constituição, tem-se de maneira automática a ligação com o Poder Judiciário.

O fato é que a partir do final da Segunda Guerra Mundial, a maior parte dos países ocidentais sofreu um grande avanço da justiça constitucional dentro do espaço da política majoritária, feita no âmbito do Legislativo e do Executivo, fomentada pelo voto popular, demonstrando uma fluidez do limite entre política e justiça. No caso brasileiro, por conta da extensão e volume, várias circunstâncias ligadas à Constituição, à realidade política e às competências dos poderes, têm dado grande visibilidade ao tema. As manchetes sobre assuntos decididos pelo Supremo Tribunal Federal são recorrentes, sendo que essa visibilidade contribui para a transparência, e consequentemente para o controle social, o que em uma última fronteira, contribui para a democracia (BARROSO, 2012).

De fato, somente no ano de 2008, foram decididas pelo Supremo Tribunal Federal, no
âmbito de ações diretas - que compreendem a ação direta de inconstitucionalidade
(ADIn), a ação declaratória de constitucionalidade (ADC) e a arguição de
descumprimento de preceito fundamental (ADPF) - questões como: a) o pedido de
declaração de inconstitucionalidade, pelo Procurador-Geral da República, do art. 5o
da Lei de Biossegurança, que permitiu e disciplinou as pesquisas com células-tronco
embrionárias (ADIn 3.150); b) o pedido de declaração da constitucionalidade da
Resolução no 7, de 2006, do Conselho Nacional de Justiça, que vedou o nepotismo
no âmbito do Poder Judiciário (ADC 12); c) o pedido de suspensão dos dispositivos
da Lei de Imprensa incompatíveis com a Constituição de 1988 (ADPF 130). No
âmbito das ações individuais, a Corte se manifestou sobre temas como quebra de
sigilo judicial por CPI, demarcação de terras indígenas na região conhecida como
Raposa Serra do Sol e uso de algemas, dentre milhares de outros (BARROSO, 2012).

Ackerman retrata que a Suprema Corte, em seu exercício de interpretação, promove a soberania popular voltada para o futuro, em busca da representação dos princípios passados concretizados em nome do povo (ACKERMAN, 2000).

Ainda pode-se dizer que o ativismo, colabora para a unidade da Constituição da República, controlando as atividades típicas dos demais poderes. No entanto, o problema é a interferência indevida nas funções também previstas constitucionalmente, o que seria um contrassenso (JUNIOR, 2011), uma vez que aplica a constituição ao intervir, mas obsta o exercício de poderes também previstos na Constituição.

É criada, assim, a difícil missão constitucional garantida ao Judiciário de, além de guardião da Constituição da República, apresentar-se como a mão armada da sociedade com o fim de concretizar os preceitos estabelecidos na Carta Federal, especialmente os direitos considerados pelo povo como direitos fundamentais, dentre eles os direitos estabelecidos no art. 227 da Constituição da República, sob pena de responsabilização civil do Estado por atos praticados pelos Poderes Executivo e Legislativo (JUNIOR, 2011). 
Assim, o que se depreende é que há uma preocupação comum a todos os doutrinadores, de que haja um novo perfil de atuação do Poder Judiciário, permitindo a efetivação dos direitos fundamentais, e a partir disso ocorrendo a materialização da Constituição, pois essa proatividade do Judiciário, gera tensão com outros poderes, mas não uma sobreposição de um poder sobre o outro, o que ocorre é supremacia da Constituição (JUNIOR, 2005).

Dworkin enfatiza que a função dos juízes é aplicar o direito criado pelos demais poderes. Teoricamente estes juízes não deviam criar direitos, num mundo ideal, mas na prática, isso não acontece, pois as leis e regras são quase sempre vagas e precisam de interpretação no caso concreto. Ainda, muitas vezes os problemas são tão novos, que os juízes precisam sim criar novos direitos, e quando assim o fazem, espera-se que ajam não como delegados do Poder Legislativo, mas como um segundo Poder Legislativo (DWORKIN, 2002).

Assim, oportunamente, Bobbio ressalta que para se garantir direitos maiores, outros podem ser suprimidos.

\begin{abstract}
Não se pode afirmar um novo direito em favor de uma categoria de pessoas sem suprimir algum velho direito, do qual se beneficiavam outras categorias de pessoas: o reconhecimento do direito de não ser escravizado implica a eliminação do direito de possuir escravos; o reconhecimento do direito de não ser torturado implica a supressão do direito de torturar (BOBBIO, 1992, p. 20).
\end{abstract}

Desse modo, urge lembrar que as prerrogativas dadas ao juiz não são privilégios, mas sim garantias, em última análise para a própria sociedade, que com um Juiz independente a democracia é concretizada e para o povo há a aplicação da justiça (SENA, 2007).

\title{
5 CONSIDERAÇÕES FINAIS
}

Quando o assunto é a interferência do Poder Judiciário em políticas públicas, o chamado ativismo judicial e a judicialização da política, há de imediato uma sensação de tensão, uma vez que o Judiciário extrapola suas funções típicas, para fazer valer a Constituição, independente do acesso político ou não aos cargos, estando em jogo direitos fundamentais não respeitados.

Lembrando que a Corte Suprema brasileira, o Supremo Tribunal Federal, é formado por cargos políticos, escolhidos dentre pessoas com extenso saber jurídico e conduta ilibada, dessa forma não há que se falar em princípio democrático não respeitado, mas sim, garantido.

Pois, críticas à atuação ativista surgem aos montes, no entanto, pouco ou nada se muda na postura dos demais poderes nesse tocante a fim de que essa interferência possa ser 
desnecessária, muito pelo contrário, a intervenção tem sido cada vez mais inescusável e urgente.

Assim, apesar de um aparente limite ultrapassado, conclui-se que o Poder Judiciário, necessita, em respeito às garantias constitucionais a serem preservadas, agir proativamente em nome de um bem maior, a coletividade, quando os demais poderes quedarem-se inertes.

\section{REFERÊNCIAS BIBLIOGRÁFICAS}

ACKERMAN, Bruce. Nós, o Povo Soberano - Fundamentos do Direito Constitucional. Trad. Mauro Raposo de Mello. Del Rey: Belo Horizonte, 2000.

ÁVILA, Ana Paula Oliveira. WIERZCHOWSKI. Mariana Ruschel. "Fair Play" na Efetivação dos Direitos Sociais. Direitos Fundamentais e Justiça, ano 7, n. 23, p. 192-225, Abril/Jun.2013. Disponível em: http://www.dfj.inf.br/Arquivos/PDF_Livre/23_Doutrina_Nacional4.pdf. Acesso em: 20 set. 2015.

BARBOZA, Estefânia Maria de Queiroz. Precedentes judiciais e segurança jurídica: Fundamentos e Possibilidades para a Jurisdição Constitucional Brasileira. São Paulo: Saraiva, 2014.

BARROSO, Luis Roberto. Judicialização, Ativismo Judicial e Legitimidade Democrática. Revista Thesis, vol.5, n. 1, 2012, p. 25, Rio de Janeiro. Disponível em: http://www.epublicacoes.uerj.br/index.php/synthesis/article/view/7433/5388. Acesso em: 20 set. 2015.

BERMAN, José Guilherme. Ativismo judicial, judicialização da política e democracia. $\begin{array}{lllllll}\text { Direito, } & \text { v. } & 1, & \text { n. } & 10, & 2015, & \text { Disponível }\end{array}$ http://revistas.unibrasil.com.br/cadernosdireito/index.php/direito/article/view/505/473. Acesso em: 20 set. 2015.

BOBBIO, Norberto. A Era dos Direitos. Trad. Carlos Nelson Coutinho. Nova ed. Elsevier: Rio de Janeiro, 1992.

DAHL, Robert A. Sobre a democracia. Beatriz Sidou (Trad.). Brasília: Editora Universidade de Brasília, 2009. 
DOBROWOLSKI, Silvio. A necessidade de ativismo judicial no estado contemporâneo. Seqüência: Estudos Jurídicos e Políticos, Florianópolis, p. 92-101, jan. 1995. ISSN 2177-7055. Disponível em: <https://periodicos.ufsc.br/index.php/sequencia/article/view/15778/14280>. Acesso em: 20 set. 2015. doi:http://dx.doi.org/10.5007/15778.

DWORKIN, Ronald. Levando os direitos a sério. São Paulo: Martins Fontes, 2002.

ESTEVES, João Luiz Martins. Cidadania e Judicialização dos Conflitos Sociais. Revista jurídica da UniFil, Londrina, Ano I - $\mathrm{n}^{\circ} 1$.

FERNANDES, Bernardo Gonçalves. PEDRON, Flávio Quinaud. O Poder Judicário e(m) Crise. Lumen Juris: Rio de Janeiro, 2008.

FERREIRA, Eber de Meira. Poder Judiciário, Ativismo Judicial e Democracia. (Dissertação) Mestrado em Direito - Faculdade de Direito da Universidade de São Paulo - USP. São Paulo. 2014.

FONSECA, J. P. Problemas Estruturais do Judiciário. 2011. 184 fl. Dissertação (Mestrado em Direito) - Faculdade de Direito, Universidade Federal do Paraná, Curitiba. 2011. Disponível em: http://dspace.c3sl.ufpr.br:8080/dspace/bitstream/handle/1884/25604/Problemas\%20Estruturais\%2 0do\%20Judiciario.pdf?sequence=1. Acesso em: 27 jul. 2015.

FONTAINHA, Fernando de Castro. Acesso à Justiça - Da Contribuição de Mauro Capelletti à Realidade Brasileira. Rio de Janeiro: Lumen Juris, 2009.

JUNIOR, Marcus Vinicius Pereira. Ativismo Judicial e Materialização das Políticas Públicas Infanto-Juvenis na Constituição da República: Fixação de planos ideais de atuação para os atores do Sistema de Garantia de Direitos (SGD). (Dissertação) Mestrado em Direito da Universidade Federal do Rio Grande do Norte - UFRN, Natal/RN, 2011.

JUNIOR, Americo Bedê Freire. O Controle Judicial de Políticas Públicas. (Coord.) Jose Roberto dos Santos Bedaque e Jose Rogerio Cruz e Tucci. Revista dos Tribunais: São Paulo, 2005. 
KELSEN, Hans. Teoria Pura do Direito. Trad. João Batista Machado. $8^{a}$ ed. Martins Fontes: São Paulo, 2012.

MONTESQUIEU, Charles de Secondat. O Espírito das Leis. Trad. Cristina Muracho.Martins Fontes: São Paulo, 2000.

MELLO, Celso. Discurso proferido, em nome do Supremo Tribunal Federal, na solenidade de posse do Ministro Gilmar Mendes, na Presidência da Suprema Corte do Brasil, em 23.4.2008. Disponível em: www.stf.gov.br/arquivo/cms/noticiaNoticiaStf/anexo/discursoCM.pdf, Acesso em: 20 set. 2015.

NETO, Adolfo Braga. Alguns Aspectos Relevantes sobre a Mediação de Conflitos in Mediação e Gerenciamento do Processo - Revolução na Prestação Jurisdicional. Coord. GRINOVER, Ada Pellegrini. WATANABE, Kazuo. NETO, Caetano Lagrasta. São Paulo: Atlas, 2013.

OLIVEIRA. Francisco José de. Famílias não legisladas: Direitos Fundamentais e Normas Constitucionais de inclusão. Dissertação (Mestrado) - Faculdade de Direito, Universidade Federal do Paraná - UFPR, Curitiba, 2006.

POLI, Gustavo Luiz; RAMOS, Flávio. Apontamentos acerca da judicialização da política no brasil. Revista Eletrônica Direito e Política, Programa de Pós-Graduação Stricto Sensu em Ciência Jurídica da UNIVALI, Itajaí, v.8, n.1, $1^{\circ}$ quadrimestre de 2013.

REVERBEL, Carlos Eduardo Dieder. Ativismo judicial e Estado de Direito. Revista eletrônica do curso de direito da UFSM, v. 4, n. 1, 2009.

SANTANA. Carla Rodrigues. Os Efeitos Jurídicos da Boa-fé subjetiva nas Famílias Simultâneas. Dissertação (Mestrado) - Faculdade de Direito, Pontífica Universidade Católica de São Paulo - PUC/SP, São Paulo, 2012.

SANTOS, Boaventura de Sousa. Pela Mão de Alice - O Social e o Político na PósModernidade. 7 ed. Afrontamento: Porto, 1994. 
SANTOS, Luiz Elias Miranda. Ativismo Judicial e Concretização dos Direitos Sociais. Revista de Estudos Jurídicos UNESP, a. 17, n. 25, 2013, p. 337-371, São Paulo.

SARMENTO, Daniel. Ubiqüidade Constitucional: os dois lados da moeda. Revista de Direito do Estado, v. 2, 2006.

SENA, Adriana Goulart de. Formas de Resolução de Conflitos e Acesso à Justiça. Revista do Tribunal Regional do Trabalho da $3^{\text {a }}$ Região, Belo Horizonte, MG, v.46, n.76, p.93-114, jul./dez.2007. Disponível em: https://www.trt3.jus.br/download/artigos/pdf/20_formas_resolucao_conflitos.pdf. Acesso em : 19 jul. 2015.

SILVA, Adriana dos Santos. Acesso à Justiça e Arbitragem - Um Caminho para a crise do Judiciário. Manole: São Paulo, 2005.

SILVA, Luciana Aboim Machado Gonçalves da. Mediação interdisciplinar: mecanismo apropriado para resolução de conflitos familiares.In_SILVA, Luciana Aboim Machado Gonçalves (Org). Mediação de Conflitos. Atlas: São Paulo, 2013.

SILVA, Virgílio Afonso da. Direitos fundamentais. Ed. Malheiros. São Paulo: 2009.

TEIXEIRA, Anderson Vichinkeski. Ativismo judicial: nos limites entre racionalidade jurídica e decisão política. Revista Direito GV, v. 8, n. 1, p. 1-57, 2012.

VIANNA, Luiz Werneck. BURGOS, Marceli Baumann. SALLES, Paula Martins. Dezessete anos judicialização da política. Tempo social, revista de sociologia da USP, v19. n.2. Novembro, 2007.

VIEIRA, Oscar Vilhena. Supremocracia. Rev. Direito GV. V. 4. N.2. p. 441-464, jul/dez 2008, São Paulo.

WARAT, Luis Alberto (Org.). Em Nome do Acordo - A mediação no Direito. $2^{\text {a }}$ Ed. Argentina: Almed- Angra impressiones, 1999. 